УДК: 7.026.2, 7.035(420)26, 73.027.2

ББК: 85.13

A43

DOI: $10.18688 / \mathrm{aa} 200-1-8$

S. Rambaldi

\title{
Two Borderline Works: The Miniature Classical Friezes by John Henning
}

In recent times, I was commissioned to rearrange a plaster cast collection of ancient sculpture, dating from the last decades of the $19^{\text {th }}$ century, belonging to the Department of Cultures and Societies of the University of Palermo in Italy. After a hard work of recovery, involving also the restoration of various pieces, the gallery of plaster casts was inaugurated and opened to the public on February 27, 2018, with the name "Gipsoteca del Dipartimento Culture e Società" (Ill. 6). The collection comprises a total of forty casts, a big part of which had been kept in a warehouse for fifty years. Among the forgotten casts I found two items, both framed in wood, of great interest. They are plaster replicas of two reproductions, complete but greatly miniaturized, of two very important Greek friezes of classical age ${ }^{1}$. The first one is the most famous of all Greek friezes, the Parthenon frieze, depicting the annual Panathenaic procession, by which every year the Athenians offered a sacred peplum to their guardian goddess Athena (Ill. 7). The other one is the frieze of the temple of Apollo Epikourios at Bassae, close to the modern village of Phigaleia, in the heart of the Peloponnese (Ill. 8). Like most part of the Athenian frieze, this second figurative series, representing scenes of Amazonomachy and Centauromachy, is on display at the British Museum in London².

The two miniaturized friezes are divided into various parallel rows, following the course of the figurative sequences, originally arranged along the four sides of the naoi which hosted them (in the Parthenon outside the naos, in the temple of Bassae inside). The Parthenon frieze is divided into six rows, with a 1-20 scale reduction; therefore, as the original frieze is one metre high, each short row is about five centimetres high, that is two inches according to the British system. The Bassae frieze is divided into five rows and its figures appear larger, because the metrical relation is here on a 1-10 scale, maybe to compensate for the smaller length of this latter figurative series. Moreover, whereas the Parthenon replica faithfully reflects the original

\footnotetext{
1 See [28, pp. 96-99, no. 31, and pp. 110-111, no. 36]. About the history and the formation of the Palermo collection, created by the Sicilian archaeologist Antonino Salinas (1841-1914), see [28, pp. 13-30].

2 A basic bibliography about the Parthenon frieze must comprise at least $[1 ; 3 ; 4 ; 16 ; 24]$. Fundamental studies of the sculpted frieze of the temple of Bassae are [5; 10; 17; 19, pp. 38-99 and 113-117, nos. 129-205].
} 


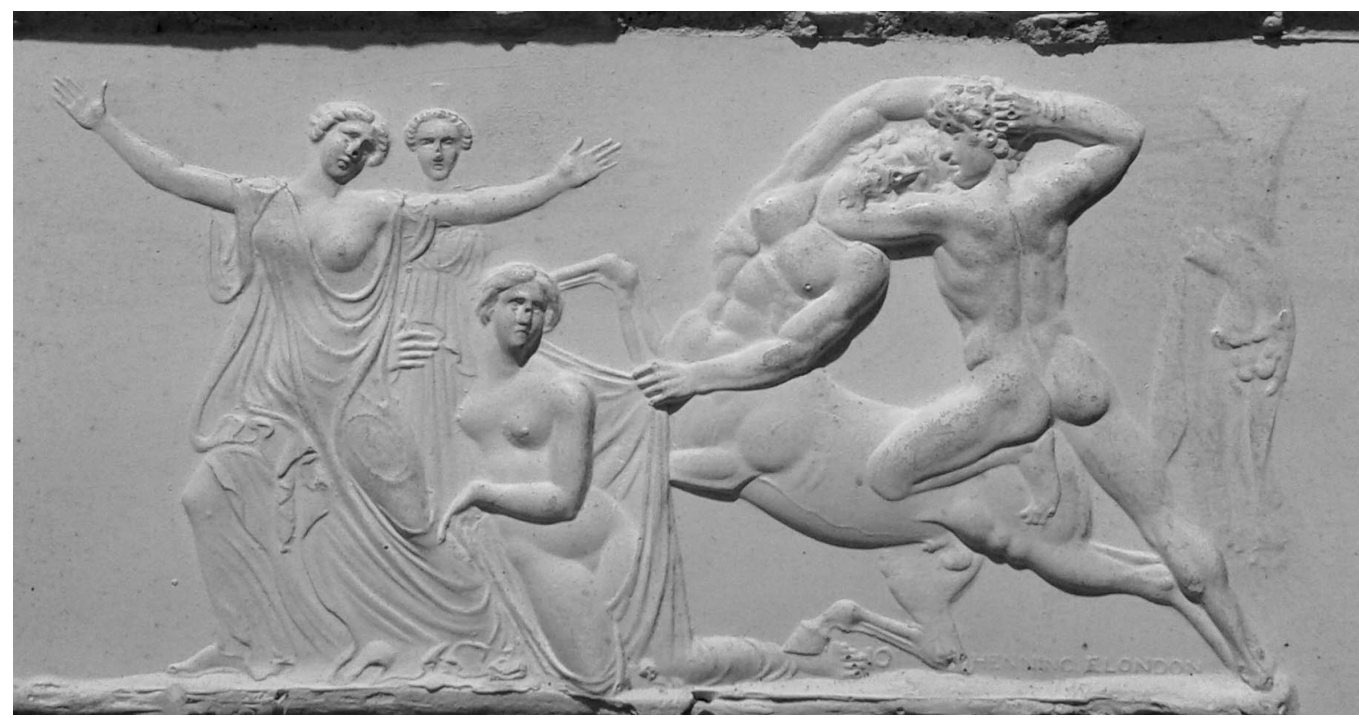

Fig. 1. The Bassae frieze by Henning. Detail: scene of Centauromachy. (c) Gipsoteca del Dipartimento Culture e Società

sequence of the frieze ${ }^{3}$, the one of Bassae does not correspond with the order of the marble slabs displayed nowadays in the British Museum, following Peter Corbett's interpretation ${ }^{4}$.

The author of these extraordinary reductions of the two classical friezes was John Henning, a name very little known to the archaeologists today, but not unfamiliar to the British historians of modern art for a reason that will be clear at the end of this paper. John Henning was a Scottish self-taught sculptor, born in 1771 at Paisley, near Glasgow, who died in London in $1851^{5}$. He had already acquired a fair reputation, as author of many portraits of prominent people on gems and cameos when he arrived in London in 1811 and happened to see the Parthenon marbles. A great part of them was already transferred to the British capital, on Lord Elgin's initiative, and they still belonged to him when Henning saw them. The sculptures would be purchased by the British Museum only in $1816^{6}$. Henning, like most of his contemporaries, was deeply impressed by the view of the Parthenon marbles, so much that he decided to make a complete reproduction of them, though miniaturized. He obtained the permission to do this work from Lord Elgin and began immediately.

Henning devoted himself to the job as if it was one of the many works of little carvings which made him famous. First of all, he drew some sketches of the sculptures. Then, after the first attempt to carve a miniature version of the Parthenon frieze in ivory, he decided to

3 In the cast, the two original short sides of the Athenian frieze correspond to the first and the forth rows (from top downwards), whereas each long side of the frieze is divided into two rows, respectively the second and the third, the fifth and the sixth.

${ }_{4} \quad$ For the problems posed by the discussed arrangement of the Bassae slabs, see [17; 19, pp. 38-40]. In the next pages, I shall make reference to the interpretation given by [19].

5 The principal studies on Henning's life and works are [20 and 36]. Malden's book [20], useful above all for the original correspondence of Henning it reports, is hard to be precisely quoted, because its pages are not numbered.

$6 \quad$ For a good reconstruction of Elgin's life and vicissitudes, see [31]. 


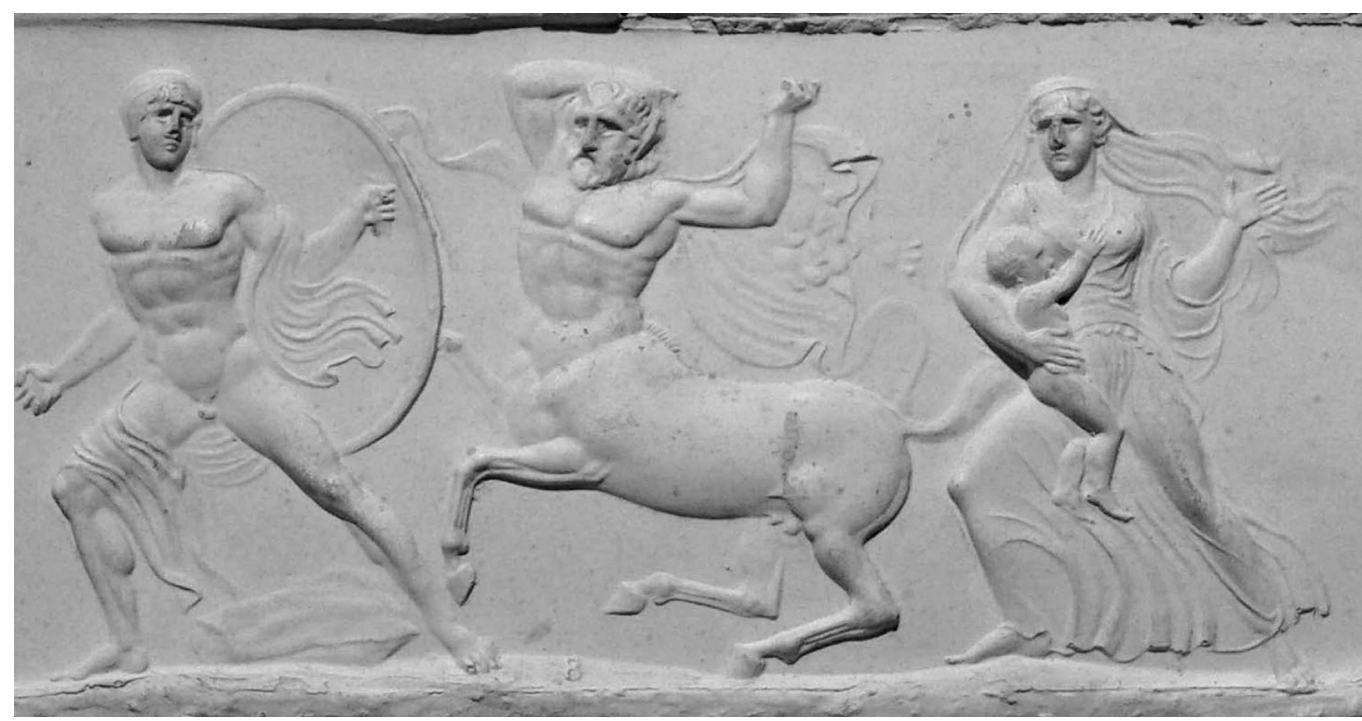

Fig. 2. The Bassae frieze by Henning. Detail: scene of Centauromachy. (C) Gipsoteca del Dipartimento Culture e Società

reproduce the figurative sequence in reverse on a series of small separate slate plates, each of them about $15 \mathrm{~cm}$ long ( 6 inches) and $5 \mathrm{~cm}$ high ( 2 inches). From these small plates, very faithful to the original and in highly reduced size, he could easily get some positive copies in plaster to be sold to anybody who was interested in them. Henning did not restrict himself to copying only the Elgin Marbles in London, but wanted to reproduce the entire Athenian frieze. For this purpose, in order to restore the lost parts and replace the ones never arrived in London, he used the sketches made by people who had seen them on the spot before, especially the precise drawings by the $17^{\text {th }}$-century French painter Jacques Carrey, even today an irreplaceable instrument to learn about the destroyed sculptures of the Parthenon [2;15, p. 152; 36, pp. 85-88]. Henning's job, as we can easily imagine, was very long and tiring: he spent nine years to complete his replica, but that was not enough for him. In 1820, he decided to spend three more years in order to reproduce even the Bassae frieze, whose slabs were located in the British Museum collections in 1815, just when Henning was working on his Parthenon reduction ${ }^{7}$. Nowadays, the original slate plates and plaster casts of both miniaturized friezes belong to the British Museum [36, p. 191]. Modern replicas are now on sale in its shop.

The casts, which Henning drew from his little plates for sale, did not have the shape of unitary panels, such as the replicas in Palermo and elsewhere. In the case of the Parthenon, he decided to reassemble the plaster segments, corresponding to the single small slate plates, in six different rows by dividing the four original sides of the frieze into six parts, the same we can see in the replicas on a panel. As Henning declared in an advertisement publicized by himself, every row was 46 to 54 inches long (for a total length of 24 feet 4 inches = about

To know how the Parthenon and Bassae marbles were exposed at the time of Henning's work, see [12, pp. 75-80]. 


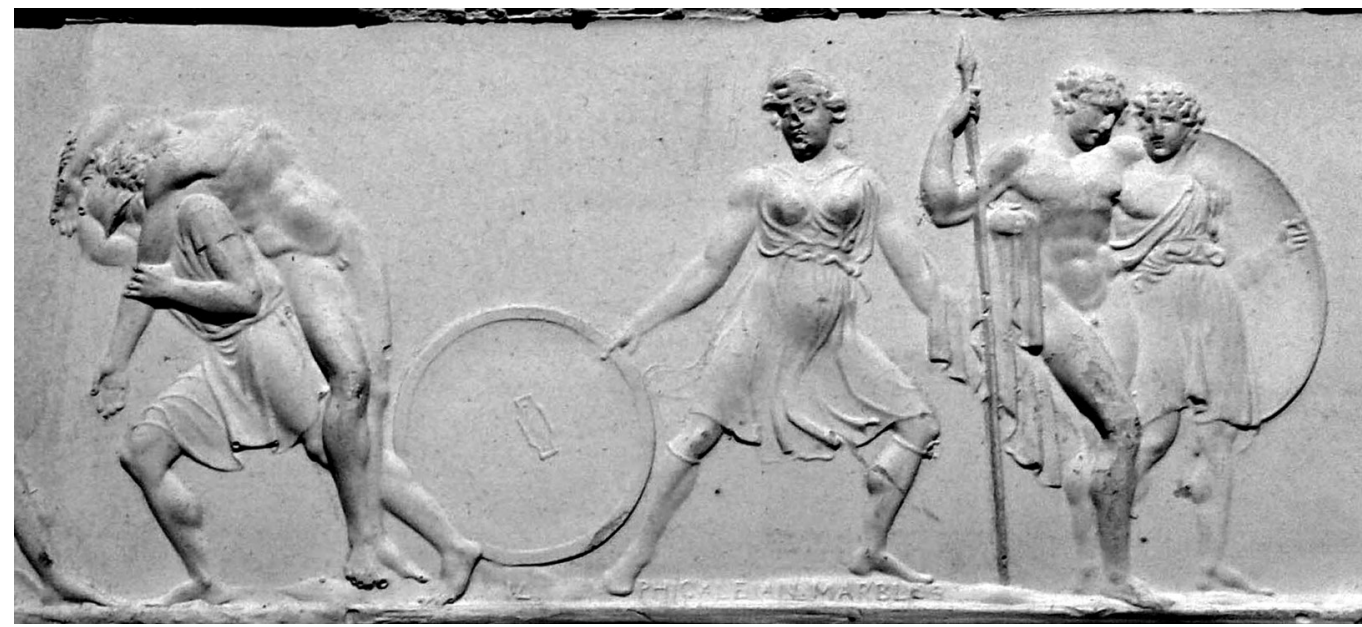

Fig. 3. The Bassae frieze by Henning. Detail: scene of Amazonomachy. (C) Gipsoteca del Dipartimento Culture e Società

$730 \mathrm{~cm}$ ) and had its own frame made of oak wood. Different parts of the frieze could be sold either together or separately. In the same advertisement, he specified that his artifacts not only would be an elegant ornament for chimneys, but also could fit libraries if they were inserted into mock volumes.

Despite his entrepreneurship, Henning was betrayed by the utmost easiness of duplicating his works. A lucrative trade of pirate copies soon arose spreading even outside of Great Britain, so the unlucky carver could not make any profit. Someone unknown to us had the idea of conflating the single parts of the friezes replicated by Henning into unitary panels, which could be multiplied on an industrial scale, like the casts in Palermo. On one hand, this procedure made the action of duplication easier, though such products were copies of copies and therefore of inferior quality; on the other hand, it allowed to give back their unity to the two figurative series as each one could be admired and studied more leisurely in a single composition. Henning maybe imagined a higher-level public for his original creations, but the pirate panels were certainly more available, for the benefit of a larger mass of visitors. They looked like pictures, ready for embellishing the walls of sitting rooms and lounges in private houses. We cannot know how many of these plaster panels, manufactured in the $19^{\text {th }}$ century mostly by French and Italian workshops, are preserved in the world today, but certainly, they became greatly widespread? They were purchased by the keepers of plaster cast collections as well, because they appeared as an excellent aid to the study of the figurative series reproduced on them. In Italy, for instance, in addition to those in Palermo, two copies of both friezes are still preserved in the Museo dei Gessi at La Sapienza University in Rome [23, p. 55, no. 19, and p. 58, no. 8].

$8 \quad$ The original text by Henning, dated " $18^{\text {th }}$ December 1820 ", is entirely quoted in [20, no. 18]: “[...] they form elegant ornaments for a chimney-piece; or, fitted up in imitation of volumes, are adapted to the library $[\ldots] "$.

See [36, pp. $130-138 ; 38$, pp. 2-3; 39, p. 161]. It is on record that in 1835 a French workshop had sold even 12.000 pirate copies of Henning's miniatures: [36, p. 133]. See also the 1845 letter in which Henning complains the damage he had suffered as a result of piracy: [36; 20, nr. 39]. 


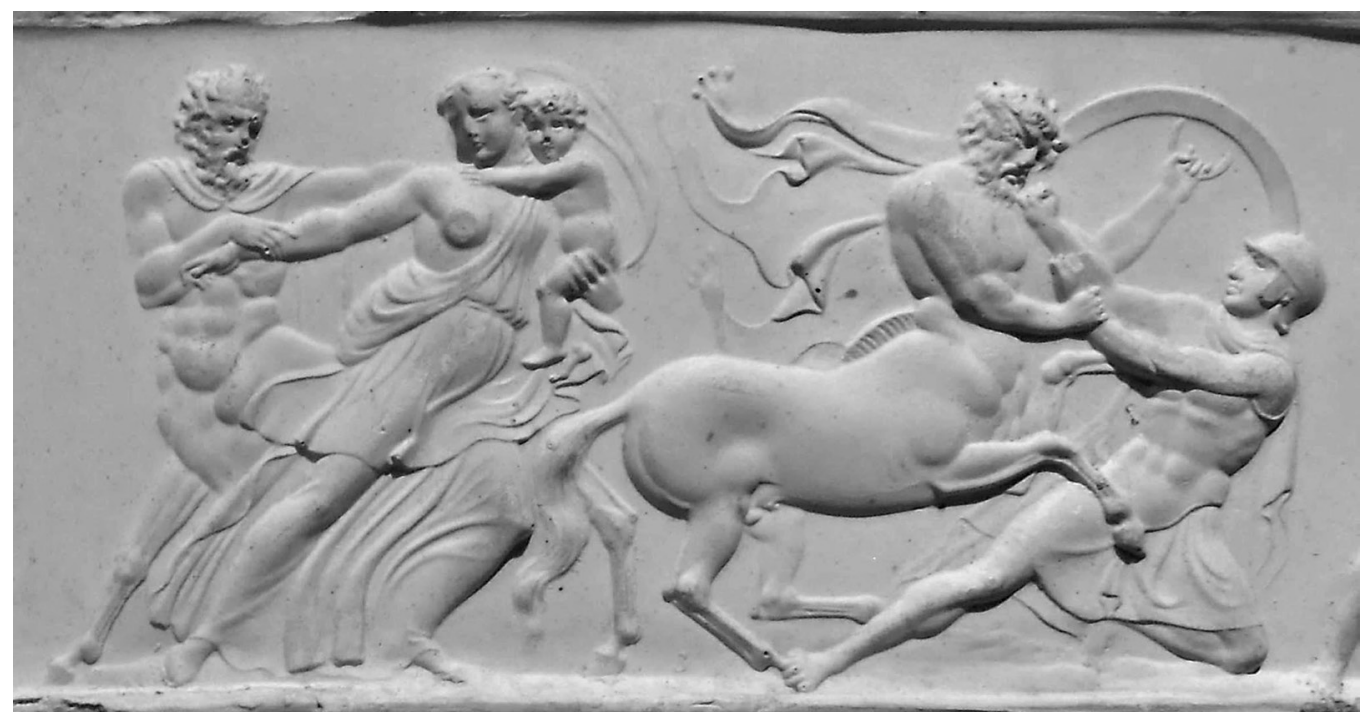

Fig. 4. The Bassae frieze by Henning. Detail: scene of Centauromachy. (C) Gipsoteca del Dipartimento Culture e Società

On both reproductions, Henning attempted in vain to insert a sort of copyright, in order to attest the paternity of his artifacts. On the original Parthenon miniatures, he carved his name (which passed on pirate replicas too) with tiny characters in relief, fir on the background of the rows primarily (but also on the seats of the gods). It appears frequently, usually in the form HENNING F, that is to say HENNING F(ECIT) in Latin terms. Often there are English words, specifying the position of the figures in the Greek frieze. For instance, under the seat of the god Hermes in the Olympian assembly (fourth row from top downwards), it is possible to read the misspelled inscription FREIZE (= FRIEZE) OF THE EAST PORTICO ${ }^{10}$. The place of production ( $L O N D O N)$, some numbers, monograms and a few dates (1818, 1819, APRIL 1820) also appear. These last ones may possibly reflect different steps of the production. The same devices were taken up in the Bassae frieze too: on the background and on the terrain under the feet of the fighters, we meet again the phrase HENNING F(ECIT), LONDON, the dates 1822 and 1823, some numbers here and there, monograms, and the phrase PHIGALEIAN MARBLES frequently repeated. In the replicas in the shape of a panel, some different and bigger Latin inscriptions in Bodoni characters are added in the spaces along the extremities of the rows of figures. In the Parthenon reproduction, these lateral inscriptions specify the subjects of each original side of the frieze $\mathrm{e}^{11}$; in the Bassae cast, on the contrary, only the provenance of the reliefs and their place of preservation are indicated, with a few spelling mistakes ${ }^{12}$.

10 Maybe the error was determined by the reverse course of writing in the original miniatures.

11 For example: POMPA / PANATHENAICA and IN PARTHENONI[S] / LATERE OCCIDENT[ALI] on the sides of the first row above; HEROVM / CONSESSVS and SVPRA PARTHENON[IS] / PORTAM ORIENTALE $[M]$ on the sides of the fourth one, where the assembly of the gods and heroes is represented.

12 ZOOPHORVS TEMPLI / PIHGALIENSIS (= PHIGALIENSIS) and IN MVSEO (= MVSAEO) BRITANNICO / ADSERVATVS. 


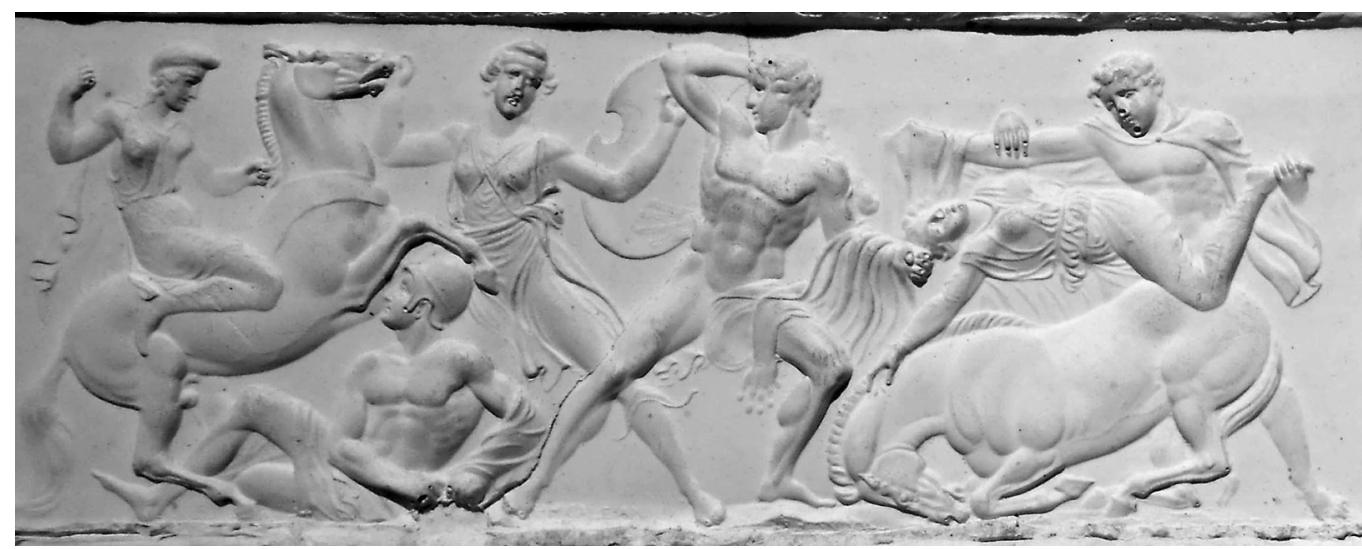

Fig. 5. The Bassae frieze by Henning. Detail: scene of Amazonomachy. (c) Gipsoteca del Dipartimento Culture e Società

Henning strove to replicate both friezes in the most precise and faithful way. Nevertheless, he was forced to add some invented details and his hand was influenced by the contemporary aesthetic taste, as can be noted in many excerpts. From the sharp and chiseled contours of the carved figures a more neoclassical than classical aura emanates, above all in the parts of the Parthenon frieze not directly known by the author ${ }^{13}$. In order to report some examples of this way of reproducing, for lack of space I prefer to concentrate my attention on the replica of the Bassae series, because, among the few studies about Henning and his works, it has aroused less interest than the Athenian one so far. Anyway, most features are common to both artifacts, as I shall try to point out.

The first characteristic that separates the copy from its model is the greater airiness of the whole, with a more sensible (and more neoclassical) detachment among the figures and larger parts of free space among the episodes, whereas the original composition shows a heavier crowding. A second evident characteristic is not only referable to a matter of taste, but also caused by the nature of the reproduction and by its tiny size. It is the strong flattening of the relief, which squeezes many figures on the background, producing an effect like Donatello's stiacciato, obviously on a much narrower scale. For example I quote a detail of the Bassae frieze showing one of the animated scenes of the fight between the Centaurs and the Lapiths (slab BM 524 [19, pp. 80-81 and 113, no. 133]): on the left, in a sanctuary of Artemis, two Lapith women with an image of the goddess have sought shelter from the assault of a Centaur. This is held back by a young man who rushes to the rescue of the women (Fig. 1). The flattening of the relief in the copy, in comparison with the original, appears very clear in the body masses and in the folds of the clothes, as well as in the trunk with a hanging panther skin on the right and in the statue of Artemis. Marked frontality, absent in the original frieze, was also added to the face of the goddess, maybe not meant by Henning as a work of sculpture carried by the kneeling woman, but perhaps as another living girl. Such modifications, as I have just noted, are the result of the nature and the restricted size of the replica. But, as always in both friezes, we can anyway recognize carver's great

13 An acute analysis of some segments of Henning's Parthenon frieze, with an accurate description, in [39, pp. 161-164, figs. 8-12]. 
care for the tiniest subtleties of the figurative story. It is worth noticing, for instance, the detail of the Centaur trying to hold back his female victim by trampling on her leg with his right hind hoof scrupulously reproduced by Henning. In the copy, however, we can observe a light anomaly, seemingly insignificant, but related to the aesthetic taste of the early $19^{\text {th }}$ century. It concerns the hair of the Greek (probably Theseus) attacking the Centaur from behind: whereas in the original, he like his companions has the short hair, which is typical of a young man in classical art, his image reduced by Henning shows curly and thicker hair, giving a "Regency style" appearance to the nude fighter. The same peculiarity comes back elsewhere, for instance in another episode of fight between a man and a Centaur, where the former (maybe one of the Dioscuri), with a thick head of hair, is grabbing a hand and a leg of the latter (BM 526 [19, pp. 79-80 and 113, no. 135]).

After the iconographic closeness, Henning's deepest interest was to get two entire reproductions of the Parthenon and Bassae friezes. He wanted to not only replace the missing parts, but also restore the damaged figures, in order to reestablish the completeness of the original compositions. Sometimes his restoration work produced positive results, sometimes not. In a scene involving two fighters and a Lapith woman (BM 525 [19, pp. 81 and 113, no. 134]), we can easily observe that, except for the Centaur, the faces of all the people were renewed including the child in woman's arms (Fig. 2). The wild skin with the muzzle and paw whirling behind the Centaur can be also ascribed to Henning's inventiveness. Here the carver misinterpreted the swirling mantle in the sculpted image, as it is easily confirmed by a comparison not so much with the damaged marble frieze, as with an engraving by Otto Magnus von Stackelberg ${ }^{14}$. On this point, Henning was probably inspired by other details of animal skins, which he could see in different parts of the frieze just as in the episode of the fight at the sanctuary that we have examined before. Another widely restored scene representing a truce after the battle, belongs to the Amazonomachy series ${ }^{15}$ (BM 539 [19, pp. 72-73 and 114, no. 148]), where Henning was forced to restyle several details: the entire torso of the dead warrior carried away on companion's shoulders on the left, the head of the central Amazon holding her shield upright on the ground and the heads of the two figures on the right, at the end of the composition (Fig. 3). In this scene, an imaginary detail is also recognizable: the man carrying his companion on the left keeps a helmet on. Did he really wear it? What is preserved of the relief cannot allow us to verify with certainty, but it seems very improbable ${ }^{16}$. In another Centauromachy scene (BM 522 [19, pp. 82 and 113, no. 131]), we can note the addition of a helmet, looks more Roman than Greek on the Lapith in cuirass on the right who is digging his knee into the ground and turning back toward the Centaur who is trampling him (Fig. 4). In this helmet, more suitable for a Roman legionary, Henning's pursuit for fidelity to the original definitely failed ${ }^{17}$.

14 In 1826 von Stackelberg published a complete graphic reproduction of the preserved sculptures (without any restoration): see [32, pl. XX] and below, note 22 .

15 On the basis of the displayed subjects, it was proposed to distinguish between a Trojan and a Heraklean Amazonomachy: [19, pp. 70-78]. The scene under examination is included in the first one.

16 In the original slab, dress and smaller scale of the bearer suggest not a warrior, but "a slave or squire" $[19$, p. 72]. The same can be said for the figure at the right end of the scene, helping a wounded warrior leaning on his spear.

17 The carver surely drew inspiration from the other helmets visible in the frieze, but he misrepresented their shape. 
Here and there some signs of prudery appear. An episode of Amazonomachy represents in the middle a duel between the queen Hippolyta and Heracles (BM 541 [19, pp. 76 and 114-115, no. 150]). The Amazon (head restored by Henning) is identifiable through her dress, while the hero through his club and the lion skin on his arm. To the lion's paw hanging from the thigh of Heracles in the original relief, Henning added a hem covering the groin in his copy (Fig. 5). We can observe a similar intervention in another scene, where two Centaurs are burying the Lapith hero Kaineus who tries to defend himself by raising his shield, under a rock (BM 530 [19, pp. 81 and 114, no. 139]). In comparison with the original sculpture, the Centaur's tail on the right has been extended to cover the groin of the warrior rushing to companion's aid and grabbing the Centaur's hair. These touches of moralism, remembering the fig leaves applied to the statues long ago, look somewhat curious here, because they appear just in few points. Indeed, the nudity of the warriors is not disguised usually but it is reproduced faithfully like in the original. It is hard to understand, therefore, why the search for decency appears only occasionally, unless Henning thought that some parts of his miniatures could be isolated from the other ones, perhaps in view of a particular kind of customers.

Apart from these small details, the two artifacts are the trustworthy replicas of sculptural reliefs dating back to the apogee of the Greek artistic production. But, at the same time, they are also two typical "industrial" products of the $19^{\text {th }}$ century, as it is indicated by their ways of duplication and diffusion, as well as by their destination. Now what we must consider is the following: in what way did Henning's work contribute to the knowledge and the modern fame of the two classical friezes, especially of the more celebrated of the two? It seems quite likely that the renown of the two figurative works was essentially determined by the sculptures themselves, which since their appearance excited an enormous sensation and animated discussions among the scholars and artists. It is a well-known fact that the great Antonio Canova was deeply struck by the vision of the Parthenon reliefs, so much that he refused the request to restore them, as if it was a sacrilege [7, pp. 23-35; 25; 26, pp. 277-278, 284-285, $300-306]$. The duplicates of Henning's miniatures surely circulated among the plaster cast galleries, but the big collections preferred to get at least some copies on a 1-1 scale, in order to study and appreciate the stylistic features of the originals. Many succeeded in obtaining them very early thanks to the British Museum itself [7, pp. 35-40; 11; 24, pp. 232-237; 26, pp. 309312]. In the Plaster Cast Gallery of Palermo, in addition to the version in miniature, four casts of the Parthenon frieze of the same size as the original marble slabs are preserved. Many more plaster cast collections in the world have a greater number of them, even of the entire frieze ${ }^{18}$.

Henning's artifacts are of special interest to us, because they are on the border between different levels: between ancient and modern, art and handicraft, public and private, study and pleasure. However they seem to have been, in their times, more a curiosity than an instrument really helping the modern study of those classical friezes. On the other hand, their

18 For the casts in Palermo, see [28, pp. 100-109, no. 32-35]. They were manufactured by a Roman workshop of castmakers, the Gherardis, working in the last decades of the $19^{\text {th }}$ and in the early $20^{\text {th }}$ century; about their activity, see [21]. A complete plaster reproduction of the Athenian frieze, for instance, can be admired in Moscow, at The Pushkin State Museum of Fine Arts (in addition to the stone reliefs, replicating parts of the Parthenon sculptures, in the porticoes along the façade of the main building: see [30, p. 81]). 
author was moved by business aims, though he failed to succeed ${ }^{19}$. Going over the influence of the Parthenon and Bassae sculptures on modern artists lies outside the goal of my work. But, I would only like to remember that the effect of those figurative series on European art was great: there are even some known wallpapers replicating the Parthenon frieze ${ }^{20}$. After all, this fortune had already started before the original marbles left Greece. For instance, the row of female figures drawn by John Flaxman in 1795 for the Choephores by Aeschylus [34, p. 136, fig. 38], even if it is different in its theme and shows other figurative influences as well (especially from Greek vase painting), seems to retain some memory of the Athenians girls parading in the Panathenaic procession. The Parthenon frieze, at that time, has not yet reached England, but Flaxman might have known it through the plates of the second volume (London, 1787) of a very celebrated publication, the Antiquities of Athens set up by James Stuart and Nicholas Revett, where the Panathenaic sculptures had already been reproduced ${ }^{21}$. These engravings, after drawings by William Pars [15, p. 152], had got such a large spread all over Europe and had handed down to the artists such an image of the frieze already toned in a classicistic sense, that they could have exerted some influence even on Henning's work. The Bassae frieze also, immediately after its arrival in London, was graphically reproduced for the first time in the successful book by Johann Martin Wagner published in Rome in $1814^{22}$. Within this large circulation of the knowledge of the Athens and Bassae friezes, Henning's miniatures occupied a definitely marginal position. They were more an early product of the fame of the friezes, than an active part in the process by which modern culture took possession of the classical heritage. They were much more an effect than a cause.

It remains to examine shortly the influence of the two friezes on the sculpted decoration of some new buildings erected in London in the first decades of the $19^{\text {th }}$ century, a period of a renovated Greek fashion in the British architectural style [6, pp. 21-24; 22]. Greece looked like a cultural symbol of freedom, above all after the final defeat of Napoleon, who was considered almost as a modern "Roman" emperor [9; 13]. It is a chapter we cannot forget, after discussing Henning's activity, because he was himself a protagonist of the phenomenon of the "Greek Revival" at that age. He and his son, John Henning junior, indeed were commissioned to decorate some important buildings of London. They particularly sculpted the exterior friezes

19 Besides, Lord Elgin himself regarded that the knowledge of Parthenon marbles, carried to London by him, would be "to the advantage of manufacturers": see [27, particularly p. 476]. He primarily thought of the ornamentation of furnishings.

20 See [14, pp. 178-179, fig. 6]. In the portion of a wallpaper reproduced by Jenkins, a touch of prudery appears like those noted before in Henning's work. On the influence of the Elgin marbles on a more general plane, see $[8 ; 18 ; 29$, chiefly pp. 446-449].

${ }_{21}$ See particularly (pl. XXII) in that volume. The slabs of the frieze are there singularly reproduced in (Chap. I, pls. XIII-XXX). The last plate of the series shows a graphic conflation of the slabs then watched. It is distributed into six rows, similar to the arrangement in the reduced plaster casts, but with a reversed order. About the Antiquities of Athens, see [33, pp. 122-130].

22 The book came out just a year before the sculptures of the temple reached the British Museum [35; see 12, p. 79]. Just few years after their arrival to London, as stated above in 1826, Otto Magnus von Stackelberg published his even more renowned work, containing a complete graphic reproduction of the preserved sculptures [32]. The sequence of the slabs here published corresponds to the order of the scenes reproduced by Henning. In addition to the plates showing a single part of the frieze [32, pls. VII-XXIX], all the scenes, arranged on two rows, are conflated in $[32, \mathrm{pl}$. VI]. 
decorating two buildings designed by the architect Decimus Burton: the Hyde Park Screen (1825-1827) and the Athenaeum Club on Pall Mall (1828-1830) [15; 29, p. 447 and note 11; 36 , pp. 101-102, 164; 39, pp. 170-173]. The sculptures, this time of large size, distinctly imitated the Parthenon frieze. But, in the former case, the Hennings accomplished a work freer and less dependent on the model, even in the choice of the represented themes, whereas in the latter they faithfully reproduced about a half of the original. Henning the Senior might have used his miniaturized version as an aid for carving the Athenaeum frieze, because within it the missing parts which he already reconstructed in that previous occasion also appear.

Other replicas of the Parthenon frieze were carried out to decorate some interiors of British residences at that time [36, pp. 102-115, figs. on pp. 116-120], while the Bassae frieze was less reproduced. An excellent indoor copy of this latter was accomplished, but not by Henning, along the top of the walls in the library of the Travellers Club, another exclusive London club overlooking Pall Mall whose present house was designed by Charles Barry in 1829 [6, p. 24]. The choice to replicate this very frieze here as a decorative element seems clear: among the founding members of that club in 1819, there was the architect Charles Robert Cockerell, the leader of the expedition which, after the first exploration in 1811, investigated the Temple of Bassae in the mountains of the ancient Arcadia and recovered its sculptures a year later. These findings then joined the collection of the British Museum in 1815, as stated above ${ }^{23}$.

Starting from that age, however, the copies of the two classical friezes became more and more rare on new buildings, because the architectural taste was changing. The Parthenon and Bassae marbles have by then become heritage of humanity.

\section{References}

1. Beschi L. Il fregio del Partenone: una proposta di lettura. Lesperimento della perfezione. Arte e società nell'Atene di Pericle. Milano, Electa Publ., 1988, pp. 234-257 (in Italian).

2. Bowie T.; Thimme D. The Carrey Drawings of the Parthenon Sculptures. Bloomington; London, Indiana University Press Publ., 1971. 98 p.

3. Brommer F. Der Parthenonfries. Katalog und Untersuchung. Mainz am Rhein, Philipp von Zabern Publ., 1977. 292 p. (in German).

4. Delivorrias A. The Parthenon Frieze. Problems, Challenges, Interpretations. Athens, Melissa Publ., 2004. $192 \mathrm{p}$.

5. Dinsmoor W. B. The Sculptured Frieze from Bassae (A Revised Sequence). American Journal of Archaeology, 1956, vol. 60, pp. 401-452.

6. Engel U. Architektur des Klassizismus und der Romantik in England. Klassizismus und Romantik. Architektur - Skulptur - Malerei - Zeichnung. Köln, Könemann Publ., 1999, pp. 14-55 (in German).

7. Farinella V. Fidia neoclassico / Fidia romantico: "una rivoluzione nel gusto". Leco dei marmi. Il Partenone a Londra: un nuovo canone della classicità. Roma, Donzelli Publ., 2003, pp. 23-48 (in Italian).

8. Farinella V.; Panichi S. L'eco dei marmi. Il Partenone a Londra: un nuovo canone della classicità. Roma, Donzelli Publ., 2003. 128 p. (in Italian).

9. Fehlmann M. As Greek as It Gets: British Attempts to Recreate the Parthenon. Rethinking History, September 2007, vol. 11, no. 3, pp. 353-377.

23 See [33, pp. 188-191; 37, pp. 12-13, 47-48, 161]. Some casts of the Bassae frieze were placed by Cockerell on the top of the walls in a few buildings designed by him, in particular Oakly Park in Shropshire (staircase: 1823) and the Ashmolean Museum at Oxford (staircase: 1839-1840). Frequently he imitated other architectural elements of the Temple of Bassae, as the Ionic capitals of the naos. See [37, pp. 160, 172, 194, 204, pls. $47,62,103,115]$. 
10. Hofkes-Brukker Ch. Der Bassaifries in der ursprünglich geplanten Anordnung. Der Bassai-Fries. München, Prestel Publ., 1975, pp. 43-141 (in German).

11. Jenkins I. Acquisition and Supply of Casts of the Parthenon Sculptures by the British Museum, 18351939. Annual of the British School at Athens, 1990, vol. 85, pp. 89-113.

12. Jenkins I. Archaeologists \& Aesthetes in the Sculpture Galleries of the British Museum 1800-1939. London, British Museum Press Publ., 1992. 264 p.

13. Jenkins I. Athens Rising Near the Pole: London, Athens and the Idea of Freedom. London - World City 1800-1840. New Haven; London, Yale University Press in association with the Museum of London Publ., 1992, pp. 143-153.

14. Jenkins I. 'G. F. Watts' Teachers': George Frederic Watts and the Elgin Marbles. Apollo. A Journal of the Arts for Connoisseurs and Collectors, September 1994, vol. 120, pp. 176-181.

15. Jenkins I. John Henning's Frieze for the Athenaeum. The Athenaeum Collection. London, The Athenaeum Publ., 2000, pp. 149-156.

16. Jenkins I. The Parthenon Frieze. London, British Museum Press Publ., 2002. 119 p.

17. Jenkins I.; Williams D. The Arrangement of the Sculptured Frieze from the Temple of Apollo Epikourios at Bassae. Sculpture from Arcadia and Laconia. Proceedings of an International Conference Held at the American School of Classical Studies at Athens, April 10-14, 1992. Oxford, Oxbow Books Publ., 1993, pp. 57-77.

18. Lydakis S. The Impact of the Parthenon Sculptures on $19^{\text {th }}$ and $20^{\text {th }}$ Century Sculpture and Painting. The Parthenon and Its Impact in Modern Times. Athens; New York, Melissa Publ., 1994, pp. 231-257.

19. Madigan B. C.; Cooper F. A. The Temple of Apollo Bassitas, vol. 2: The Sculpture. Princeton, The American School of Classical Studies at Athens Publ., 1992. 135 p.

20. Malden J. John Henning 1771-1851, “...A Very Ingenious Modeller...”. Paisley, Renfrew District Council Museum \& Art Galleries Department Publ., 1977 (unpaginated).

21. Malone P. The Gherardis Castmakers in Paris and Rome. In Situ, 2016, vol. 28. Available at: http://insitu. revues.org/12712 (accessed 30 January 2019).

22. Mordaunt Crook J. The Greek Revival. Neo-Classical Attitudes in British Architecture 1760-1870. London, John Murray Publ., 1995². 204 p.

23. Morricone M. L. Il Museo dei Gessi dell'Università di Roma. Roma, Istituto Poligrafico e Zecca dello Stato, Libreria dello Stato Publ., 1981. 155 p. (in Italian).

24. Neils J. The Parthenon Frieze. Cambridge, Cambridge University Press Publ., 2001. 294 p.

25. Pavan M. Antonio Canova e la discussione sugli "Elgin Marbles". Rivista dell'Istituto Nazionale d'Archeologia e Storia dell'Arte, 1974-1975, vols. 21-22, pp. 219-344 (in Italian).

26. Pavan M. Lavventura del Partenone. Un monumento nella storia. Firenze, Sansoni Publ., 1983. 395 p. (in Italian).

27. Pucci G. Elgin o della manifattura. Dialoghi di Archeologia, 1974-1975, vol. 8, no. 2, pp. 475-490 (in Italian).

28. Rambaldi S. La Gipsoteca del Dipartimento Culture e Società dell'Università degli Studi di Palermo. Storia e Catalogo. Palermo, Palermo University Press Publ., 2017. 130 p. (in Italian).

29. Rothenberg J. Descensus ad terram. The Acquisition and Reception of the Elgin Marbles. New York; London, Garland Inc. Publ., 1977. 469 p.

30. Savoy B.; Scott S. A European Museum-Cocktail around 1900. The Pushkin State Museum of Fine Arts in Moscow. The Museum is Open. Towards a Transnational History of Museums 1750-1940. Berlin; Boston, Walter de Gruyter Publ., 2014, pp. 77-88.

31. St. Clair W. Lord Elgin and the Marbles. Oxford; New York, Oxford University Press Publ., $1998^{3} .419$ p.

32. Stackelberg O. M. von. Der Apollotempel zu Bassae in Arcadien und die daselbst ausgegrabenen Bildwerke. Rom, O. M. von Stackelberg Publ., 1826. 148 p. (in German).

33. Stoneman R. Land of Lost Gods. The Search for Classical Greece. London; New York, Tauris Parke Paperbacks Publ., 2010². 346 p.

34. Symmons S. Flaxman and Europe. The Outline Illustrations and Their Influence. New York; London, Garland Inc. Publ., 1984. 423 p.

35. Wagner J. M. Bassorilievi antichi della Grecia o sia fregio del Tempio di Apollo Epicurio in Arcadia. Rome, Francesco Bourliè Publ., 1814. 28 p. (in Italian).

36. Wall J. "That Most Ingenious Modeller". The Life and Work of John Henning, Sculptor, 1771-1851. Ely, Melrose Books Publ., 2008. 237 p.

37. Watkin D. The Life and Work of C. R. Cockerell. London, A. Zwemmer Ltd. Publ., 1974. 272 p.

38. White F. A. The Restoration of a Georgian Period Parthenon Frieze. Florida Archaeological Survey, 2014, vol. 7, pp. 1-9. 
39. Willers D. Die gar nicht spontane Begegnung oder jeder hat den Parthenon, den er verdient. Antike und europäische Welt. Aspekte der Auseinandersetzung mit der Antike. Bern; Frankfurt am Main; New York, Peter Lang Publ., 1984, pp. 145-185 (in German).

Title. Two Borderline Works: The Miniature Classical Friezes by John Henning

Author. Simone Rambaldi - Ph. D., associate professor. University of Palermo, Viale delle Scienze Ed. 15, 90128 Palermo, Italy. simone.rambaldi@unipa.it

Abstract. The theme of the article is two plaster replicas of the miniaturized reproductions of the Parthenon and Bassae friezes made in London by the Scottish sculptor and carver John Henning in the first decades of the $19^{\text {th }}$ century. The reliefs were recently revealed during a new exhibition of the Plaster Cast Gallery, belonging to the Department of Cultures and Societies of the University of Palermo in Italy. Henning based himself on the original marbles transferred to the British capital and, in the case of the Athenian frieze, on the drawings of the missing parts. Through a long job, his reproductions in miniature were carved in reverse into slate slabs from which plaster casts were easily obtained and finally sold. A lucrative trade of bootlegged copies arose, but Henning gained nothing by that business. The duplicates spread in great numbers not only in plaster casts galleries, but also inside dwelling houses, as an ornament for walls and chimneys in living rooms.

These artifacts, although they have seldom captured the attention of the archaeologists, are of particular interest. The casts performed a twofold function: on one hand, they were useful for study; on the other hand, they were used as furnishing elements. The small casts by Henning, furthermore, were suitable for the taste of the time. Despite their astonishing fidelity to the originals, the sharp and chiseled contours of the carved figures emanate more neoclassical than classical aura, especially in the parts of the Parthenon frieze not directly known by the author. In that, we understand how these artifacts, though they are reliable reproductions of sculptures dating from the culminating point of Greek art, are also two typical "industrial" products of the $19^{\text {th }}$ century.

Henning's artwork seems to appear as a real "borderline work". It stands between the ancient and the modern, art and handicraft, public and private, study and pleasure.

Keywords: Parthenon frieze, Bassae frieze, John Henning, miniature, plaster casts

Название статьи. Две «пограничные» работы: миниатюрные классические фризы Джона Хеннинга

Сведения об авторе. Рамбальди Симоне - Ph. D., доцент. Университет Палермо, Виале делле Сиенце, 15, 90128 Палермо, Италия. simone.rambaldi@unipa.it

Аннотация. В связи с последним открытием новой экспозиции галереи гипсовых слепков Департамента культуры и общества Университета Палермо (Италия) были обнаружены два интересных произведения. Это гипсовые отливки, воспроизводящие в миниатюре фризы Парфенона и храма в Бассах, выполненные в Лондоне шотландским скульптором и резчиком Джоном Хеннингом в первые десятилетия XIX в. В своей работе Хеннинг опирался на подлинные мраморы, доставленные в британскую столицу, а также, в случае афинского фриза, на рисунки недостающих частей. Длительная работа заключалась в том, что миниатюрные воспроизведения были вырезаны из сланцевых пластин, затем с них снимались гипсовые слепки, которые и были проданы. В результате началось весьма прибыльное изготовление «пиратских копий», однако самому Хеннингу не удалось извлечь никакой прибыли из этого предприятия. Повторения расходились в большом количестве, заполняя собой не только галереи слепков, но и частные дома как настенные и каминные украшения жилых комнат.

Хотя эти произведения редко привлекали внимание исследователей, они представляют определенный интерес. Во-первых, эти слепки выполняли двойную функцию, с одной стороны, являясь объектом изучения, с другой - становясь частью домашней обстановки. Таким образом, происходил процесс «приватизации» двух важнейших произведений второй половины V в. до н. э. Кроме того, небольшие слепки Хеннинга соответствовали вкусам эпохи и представлениям об античном искусстве. Несмотря на поразительное сходство с подлинниками, жёстко высеченные контуры фигур соответствуют скорее не классическим формам, а духу неоклассицизма, в особенности в тех частях композиции, где Хеннинг не был знаком с оригиналом. Таким образом, можно прийти к выводу, что эти отливки, являясь достоверной копией произведений древнегреческого искусства периода расцвета, одновременно могут расцениваться как типичная художественно-промышленная продукция ХIX столетия.

Работы Хеннинга можно назвать подлинно «пограничным» явлением сразу в нескольких отношениях: они находятся между античностью и Новым временем, искусством и ремеслом, общественным и частным, изучением и развлечением.

Ключевые слова: фриз Парфенона, фриз храма в Бассах, Джон Хеннинг, мелкая пластика, гипсовые слепки 


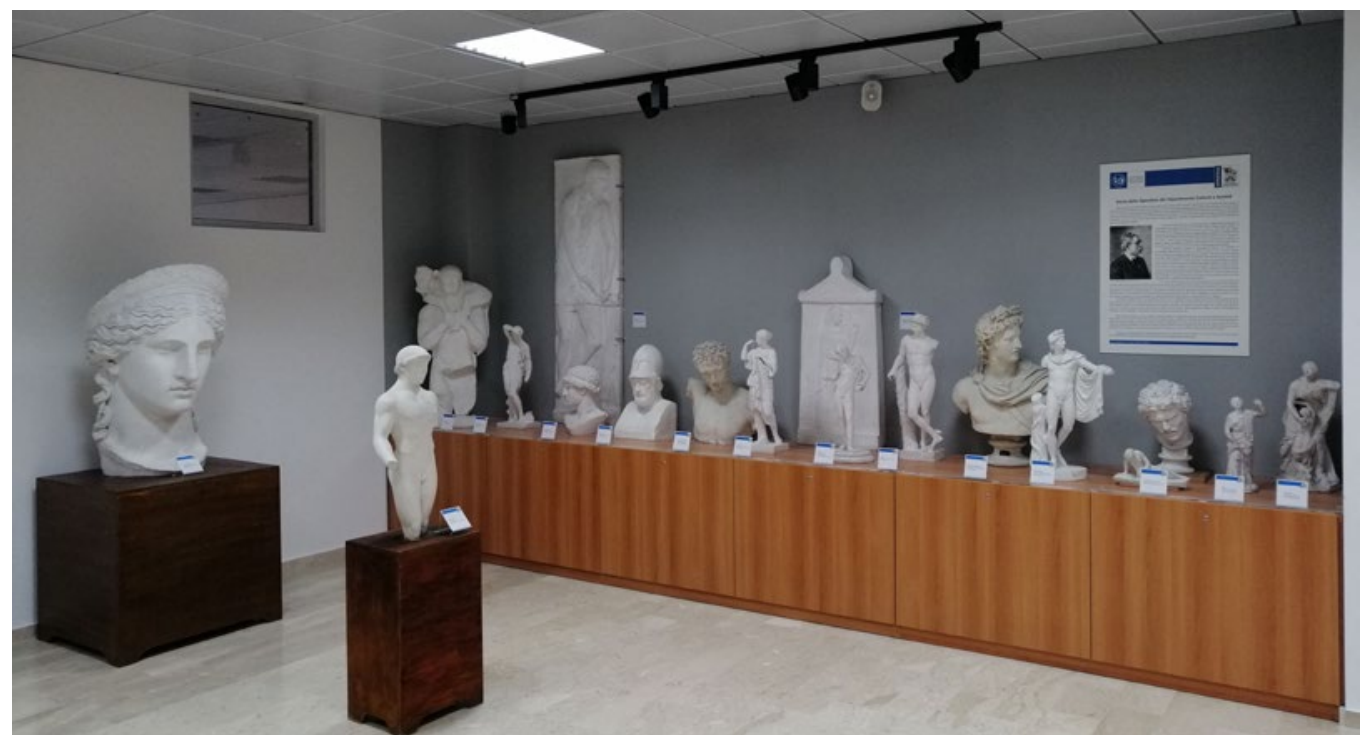

III. 6. The Plaster Cast Gallery of the Department of Cultures and Societies, University of Palermo.

Partial view. (c) Gipsoteca del Dipartimento Culture e Società

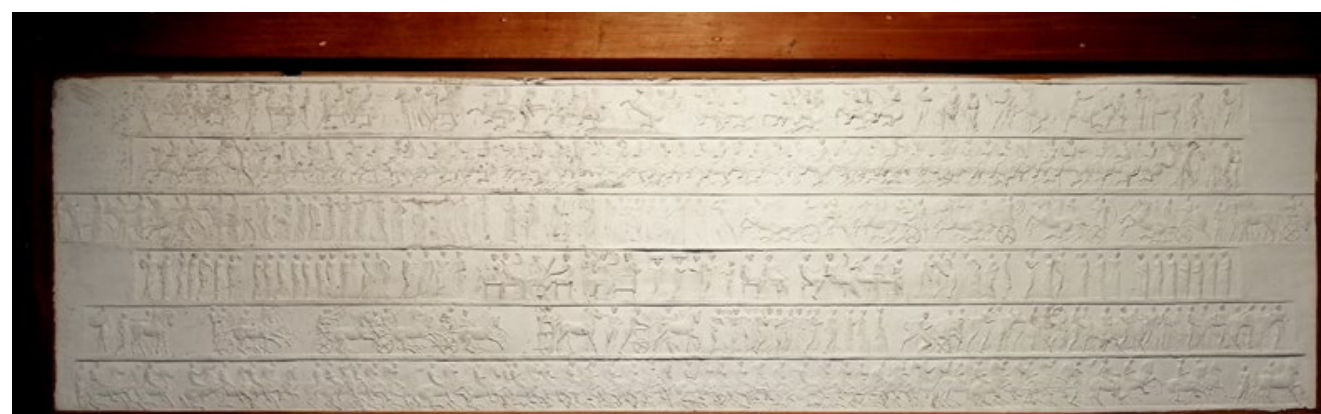

III. 7. Plaster cast of the miniaturized Parthenon frieze by John Henning (1771-1851).

(C) Gipsoteca del Dipartimento Culture e Società

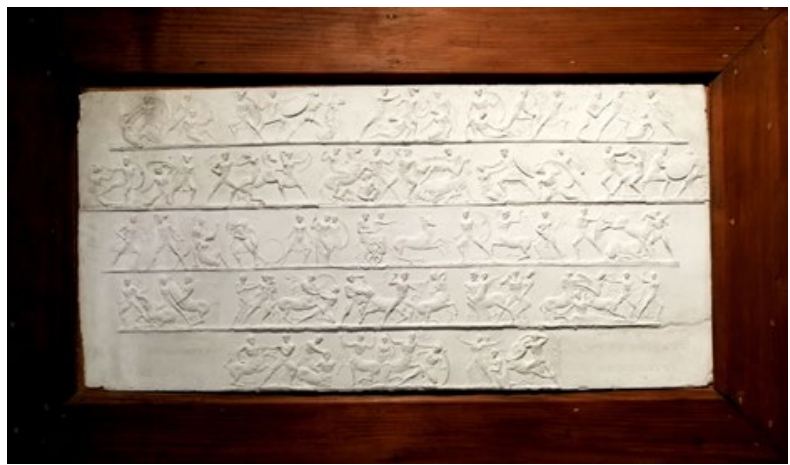

III. 8. Plaster cast of the miniaturized Bassae frieze by John Henning (17711851). (C) Gipsoteca del Dipartimento Culture e Società 